Ks. Mariusz SZRAM*

\title{
IDEA POKORNEGO UNIŻENIA W ANTYCZNEJ MYŚLI GRECKIEJ ${ }^{1}$
}

Starożytni Grecy podkreślali szkodliwość wady pychy (ơßpıৎ), nie znali jednak pokory jako cnoty ( $\tau \alpha \pi \varepsilon \imath v o \varphi \rho o \sigma u ́ v \eta)$ w późniejszym chrześcijańskim rozumieniu, co wiązało się $\mathrm{z}$ brakiem $\mathrm{w}$ ich środowisku idei wynikających z judaistyczno-chrześcijańskiego Objawienia, dotyczących: koncepcji Boga osobowego; Jego transcendencji, a zarazem kenozy; oraz swoistego rozumienia stworzenia i zbawienia człowieka i świata ${ }^{2}$. Istniały jednak w etyce antycznej pojęcia, które mogły wpłynąć na sposób wyjaśniania istoty chrześcijańskiej cnoty pokory ${ }^{3}$, co - zgodnie z zasadą akomodacji biblijnej - próbowali wykorzystać pisarze wczesnochrześcijańscy. Przykładowo Jan Chryzostom mimo krytycznego stosunku do starożytnych filozofów - skłaniał się ku przypisaniu Sokratesowi znajomości postaw zbliżonych do tej cnoty, krytykował go natomiast za niedostosowanie życia do wyznawanych zasad ${ }^{4}$.

Do swoistych „zwiastunów” cnoty pokory należała w etyce antycznej Gre-

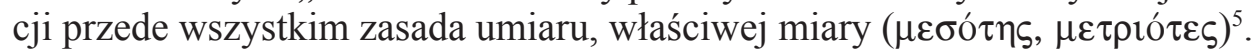
Jedną z najstarszych poetyckich zachęt do praktykowania tej postawy - „Dro-

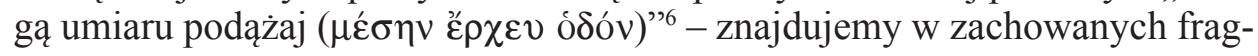

${ }^{*}$ Ks. prof. dr hab. Mariusz Szram - kierownik Katedry Teologii i Literatury Patrystycznej w Instytucie Historii Kościoła i Patrologii na Wydziale Teologii Katolickiego Uniwersytetu Lubelskiego Jana Pawła II; e-mail: m.szram@wp.pl.

${ }^{1}$ Niniejszy artykuł dedykuję ks. prof. Augustynowi Eckmannowi jako jednemu z nielicznych badaczy starożytności chrześcijańskiej, którzy zajmowali się tematyką pokory w epoce patrystycznej, szczególnie w twórczości św. Augustyna. Por. A. Eckmann, Nauka św. Augustyna o pokorze jako podstawie ascezy chrześcijańskiej, w: Wczesnochrześcijańska asceza. Zagadnienia wybrane, red. F. Drączkowski - J. Pałucki, Lublin 1993, 83-97.

${ }^{2}$ Por. V. Cathrein, Haben die heidnischen Philosophen die Demut gekannt?, „Zeitschrift für Ascese und Mystik" 1 (1926) 283-288.

${ }^{3}$ Tematyce pokory w odniesieniu do starożytnej myśli greckiej poświęcona jest praca: S. Rehrl, Das Problem der Demut in der profan-griechischen Literatur, Münster 1961 (szczególnie strony 7-146, 199-203), a także duże partie monografii: R.A. Gauthier, Magnanimité. L'idéal de la grandeur dans la philosophie païenne et dans la théologie chrétienne, Paris 1951.

${ }^{4}$ Por. Joannes Chrysostomus, In Acta Apostolorum hom. 36, 2, PG 60, 260-261.

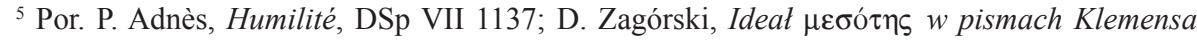
Aleksandryjskiego, Lublin 2001 (mps KUL).

${ }^{6}$ Theognis Megareus, Elegiae I 220, ed. E. Diehl - D. Young, Bibliotheca Scriptorum Grae- 
mentach elegii Teognisa z Megary (VI w.) ${ }^{7}$. Wszelki nadmiar lub brak nosił znamiona wady moralnej, cnotę natomiast charakteryzował wybór drogi pośredniej. Na świątyni w Delfach widniała sentencja - „Nic ponad miarę” $(\mu \eta \delta \dot{\varepsilon} \nu ~ \not ̈ \gamma \alpha \nu)$ - przypisywana przez Arystotelesa jednemu z legendarnych siedmiu mędrców greckich - Chilonowi ze Sparty (VI w. przed Chr.) ${ }^{8}$, a przez Diogenesa Laertiosa - innemu z siedmiu mędrców, ateńskiemu mężowi stanu, a zarazem poecie - Solonowi (ok. 640 - ok. 560 przed Chr.) ${ }^{9}$. Owa idea pojawia się najczęściej w zachowanych fragmentach pism Solona dotyczących zachowania umiaru w pragnieniu posiadania dóbr materialnych:

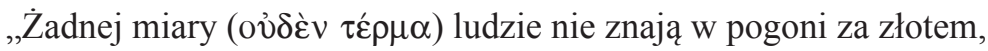
ci, co teraz bogactwa z nas posiedli najwięcej

jeszcze w dwójnasób się o nie starają; któż wszystkich nasyci?"10.

Właściwa miara nie ogranicza się jednak - zdaniem Solona - do sfery pożądania bogactw, ale odnosi się do wszelkich zakresów ludzkiej aktywności fizycznej i duchowej. Jest miara w latach życia:

„Kto zaś dziesiątą [siódemkę] przeżyje, ten miarę stosowną wypełni

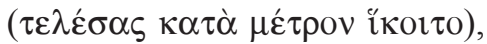

wówczas nie będzie przedwczesną śmierć, przeznaczona mu losem"11;

musi istnieć umiar w sprawowaniu władzy nad społeczeństwem:

Rzecz to najlepsza, gdy lud ze swymi kroczy wodzami, ani nadto gnębiony, ani też nadto swobodny

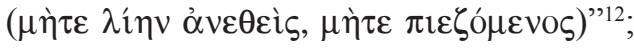

do poznania prawdy również należy dążyć szukając odpowiedniej miary w odniesieniu do dóbr intelektualnych:

„Miarę wiedzy, co jest niewidzialna, trudno uchwycić, ona zaś - jako jedyna - krańce wszystkiego ogarnia

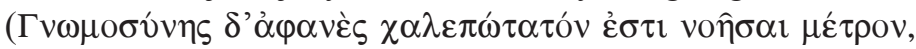

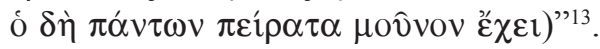

corum et Romanorum Teubneriana, Lipsiae 1961, 16, thum. W. Appel: Teognis, Elegie, w: Liryka starożytnej Grecji, opr. J. Danielewicz, Warszawa - Poznań 1996, 462.

${ }^{7}$ Por. J. Danielewicz, Wstęp, w: Liryka starożytnej Grecji, s. 103-105.

${ }^{8}$ Por. Aristoteles, Rhetorica II 12, 1389b 2-5, ed. M. Dufour, t. 1, Paris 1938, 92.

${ }^{9}$ Por. Diogenes Laertios, Vitae philosophorum I 2, 63, ed. H.G. Huebnerus, t. 1, Lipsiae 1828, 41.

${ }^{10}$ Solon, Fragmenta 5, 71-73, ed. T. Gaisford, w: Poetae minores graeci, t. 3, Lipsiae 1823, 137-138, thum. W. Appel: Solon, Fragmenty, w: Liryka starożytnej Grecji, 445.

${ }^{11}$ Tenże, Salamina, fragm. 14, 17-18, ed. Gaisford, w: Poetae minores graeci, t. 3, s. 140, thum. Appel, s. 452.

${ }^{12}$ Tamże, fragm. 21, ed. Gaisford, t. 3, s. 143, thum. Appel, s. 448.

${ }^{13}$ Tamże, fragm. 8, ed. Gaisford, t. 3, s. 138, thum. Appel, s. 451. 
Zasada umiaru przenikała także Platońską koncepcję cnót kardynalnych, zaprezentowaną w dialogu Państwo ${ }^{14}$. Wśród czterech fundamentalnych cnót

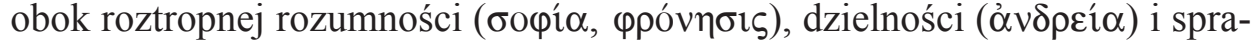

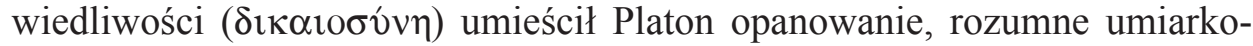
wanie $(\sigma \omega \varphi \rho o \sigma v ́ v \eta)^{15}$. Ponadto uznał sprawiedliwość, stojącą na straży odpowiednich proporcji i właściwej miary w życiu osobistym i społecznym, za zwornik i spoiwo trzech pozostałych cnót. Wyraźnie też podkreślił teologiczny wymiar postawy umiaru, wskazując na Boga jako twórcę i strażnika zasady rozumnego umiarkowania:

„rzeczy, które wykraczają poza [... właściwą miarę] ( $\tau$ ò ó $\mu \varepsilon \tau \rho \alpha)$ sobie wzajemnie nie są miłe [...] Otóż bóg ma być dla nas miarą wszystkich rzeczy

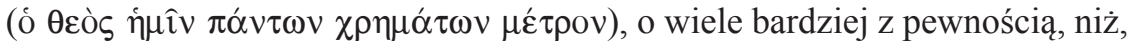
jak mówią, człowiek ${ }^{16}[\ldots]$ ten $\mathrm{z}$ nas, kto ma zdrowe poczucie umiaru, miły

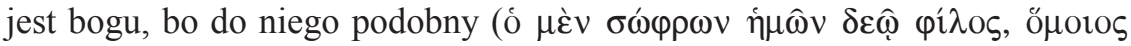

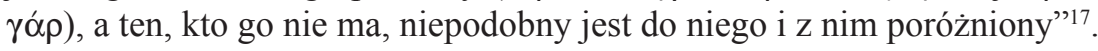

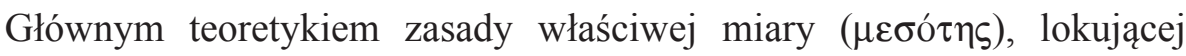
wszelką cnotę $\mathrm{w}$ słusznym środku między nadmiarem a niedostatkiem, był

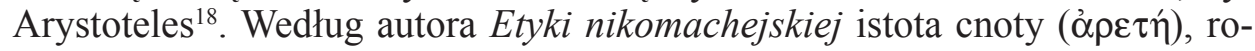
zumianej jako dzielność etyczna, czyli trwała dyspozycja do podejmowania decyzji moralnych i czynienia dobra, polega na zachowaniu średniej miary i dążeniu do środka jako swego celu ${ }^{19}$. Właściwie pojmowane cnoty oparte na zasadzie rozumnego umiaru to na przykład: męstwo będące słusznym środkiem między tchórzostwem i zuchwalstwem; wstrzemięźliwość - środek między rozwiązłością i nadwrażliwością; szczodrość - środek między rozrzutnością i chciwością ${ }^{20}$.

Poczucie konieczności zachowania właściwej miary ( $\mu \eta \delta \dot{\varepsilon} v$ ó $\gamma \alpha \nu)$ prowadziło starożytnych do przekonania o własnej ograniczoności. Wyrażało się ono w innej sentencji przypisywanej także Spartańczykowi Chilonowi i również

${ }^{14}$ Por. Plato, Respublica IV 6, 427e - 9, 432e, ed. É. Chambry, w: Platon, Oeuvres complètes, VII/1, Paris 1933, 17-26.

${ }^{15}$ Por. tamże IV 6, 427e, ed. Chambry, VII/1, s. 17.

${ }^{16}$ Aluzja do sławnego twierdzenia Protagorasa: „Wszystkich rzeczy miarą jest człowiek

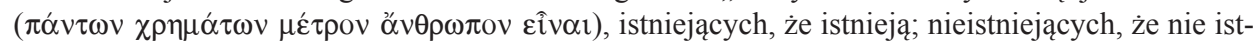
nieją", por. Plato, Cratylus 386a, ed. L. Méridier, w: Platon, Oeuvres complètes, V/2, Paris 1931, 53; tenże, Theaetetus 152a, ed. A. Diès, w: Platon, Oeuvres complètes, VIII/2, Paris 1924, 170.

${ }^{17}$ Plato, Leges IV 716c-d, ed. R.G. Bury, Loeb Classical Library, t. 1, London - Cambridge Mass. 1961, 294-296, thum. M. Maykowska: Platon, Prawa, Warszawa 1997, 148.

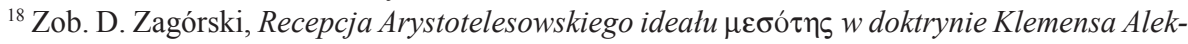
sandryjskiego. Problem definicji, RT 51 (2004) z. 4, 5-42.

${ }^{19}$ Por. Aristoteles, Ethica nicomachea II 6, 1107a, ed. F. Susemihl - O. Apelt, Bibliotheca Scriptorum Graecorum et Romanorum Teubneriana, Lipsiae 1912, 35, thum. D. Gromska: Arystoteles, Etyka nikomachejska, w: tenże, Dzieła wszystkie, t. 5, Warszawa 1996, 113.

${ }^{20}$ Por. tamże 1107b - 1108b, ed. Susemihl - Apelt, s. 36-39, thum. Gromska, s. 114-118. 
wypisanej w świątyni delfickiej: „Poznaj samego siebie” ( $\gamma v \hat{\omega} \theta \imath$ $\sigma \alpha v \tau o ́ v)$. Jej pierwotne znaczenie miało kontekst teologiczny: prawdziwe poznanie siebie prowadzi do świadomości, że człowiek jest bytem przemijającym, nie ma natury boskiej, ale śmiertelną, i w związku z tym nie może wzniośle myśleć

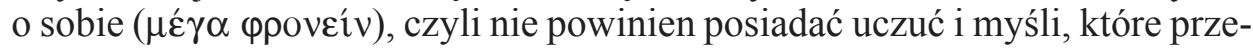
kraczają tę naturę i są właściwe tylko bóstwu ${ }^{21}$.

W przekonaniu starożytnych Greków człowiek, świadomy swoich ograniczeń, musi unikać postawy wyniosłości, hardości, zuchwalstwa i pychy, określanej terminem úßpıs. Była ona przedstawiana często jako przeciwieństwo postawy zachowania właściwej miary i jako bezpośredni skutek pogwałcenia zasady ,złotego środka" ${ }^{22}$. W antycznej Grecji uważano, że pycha jako największa $\mathrm{z}$ ludzkich wad przejawia się albo w przesadnym zadowoleniu z posiadanego bogactwa czy władzy (przypadek Krezusa, uważającego się za najszczęśliwszego z ludzi²3), albo w jawnym lekceważeniu bogów (przypadek Penteusa nie chcącego uznać kultu boga Dionizosa z Bachantek Eurypidesa ${ }^{24}$ ), stąd jest przez nich wyjątkowo surowo karana. U Teognisa czytamy:

„Bóg człowiekowi podłemu najpierw użycza

Pychy (i̋pis), by potem mu miejsca pośród ludzi odmówić”25.

${ }^{21}$ Por. Herodotus, Historiae VII 10, ed. A.D. Godley, Loeb Classical Library, t. 3, London Cambridge Mass. 1957, 318, thum. S. Hammer: Herodot, Dzieje, Warszawa 2002, 383: „,bóg wyniosłe stworzenia razi swym ogromem i nie pozwala, żeby się pyszniły [...] nie dopuszcza, żeby ktoś

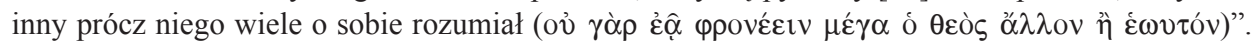
Zob. Adnès, Humilité, DSp VII 1137.

${ }^{22}$ Por. Solon, Salamina, fragm. 11, ed. Gaisford, t. 3, s. 138, thum. Appel, s. 448: „przesyt wszak

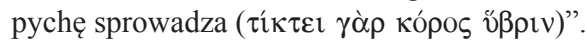

${ }^{23}$ Herodotus, Historiae I 32-34, ed. Godley, t. 1, London - Cambridge Mass. 1960, 40, thum. Hammer, s. 31: „Przy każdej sprawie należy patrzeć na koniec, jak on wypadnie: wszak wielu ludziom bóg tylko ukazał szczęście, aby ich potem strącić w przepaść. Tak powiedział Solon, ale jego słowa Krezusowi bynajmniej nie przypadły do smaku, i odprawił go, nie poświęcając mu zgoła żadnej uwagi: wydawał mu się po prostu głupcem, ponieważ nie uwzględniając szczęścia teraźniejszego, radził mu, aby patrzał na koniec każdej sprawy. Po odjeździe Solona zemsta boga ciężko dotknęła Krezusa, prawdopodobnie dlatego, że uważał siebie za najszczęśliwszego ze wszystkich ludzi”. Por. Adnès, Humilité, DSp VII 1138.

${ }^{24}$ Por. Euripides, Bacchantes Prologus 35-63, ed. E.Ch. Kopff, Bibliotheca Scriptorum Graecorum et Romanorum Teubneriana, Leipzig 1982, 4-5, tłum. J. Łanowski: Eurypides, Bachantki, w: tenże, Tragedie, Warszawa 1980, 418:

„Kadmos więc godność królewską i władzę

W ręce Penteusa dał syna swej córki,

Ten zaś z mym bóstwem walczy $(\theta \varepsilon o \mu \alpha \chi \varepsilon \hat{\imath})$ i od ofiar

Płynnych wyklucza, w modlitwach nie wspomni.

Pokażę jemu i innym Tebanom,

Że jestem bogiem".

${ }^{25}$ Theognis Megareus, Elegiae I 151-152, ed. Diehl - Young, s. 10-11, thum. Appel, s. 461. 
Zemsta bogów za postawę úßpıs przybierała niekiedy w literaturze starożytnej postać zadziwiająco zbliżoną do działania Boga opisanego w biblijnym Magnificat Maryi (por. Łk 1, 51-52):

Łatwo wywyższa, łatwo strąca on wywyższonego,

Łatwo powala pysznego, a nieznanego wynosi

(

Łatwo zgiętego sprostuje, pysznemu zaś daje uschnąć -

Dzeus, który grzmi z wysoka i mieszka w najwyższym pałacu ${ }^{26}$.

Mimo łudzącego podobieństwa intencje autorów antycznych i chrześcijańskiego Ewangelisty wydają się nieco inne. W wypowiedziach greckich poetów i prozaików obok krytyki postawy człowieka stawiającego się zarozumiale na równi z bóstwem chodzi także o bezwzględną zemstę zazdrosnego Dzeusa za okazane mu nieposłuszeństwo i wskazanie, że losami człowieka rządzi boskie fatum, od którego nie jest on w stanie się uwolnić. Autor biblijny również kładzie akcent na upodobanie Boga w zachowaniu przez człowieka posłuszeństwa i właściwego miejsca w stosunku do Stwórcy; podkreśla jednak, że Bóg zostawia wolność działania człowiekowi nie czyniąc go marionetką w swoich rękach. Bóg chrześcijan nie jest mściwy, daje tylko człowiekowi sprawiedliwą zapłatę za jego pychę, na okazanie której sam się zdecydował ${ }^{27}$.

Ucieczka przed úßpıৎ nie oznaczała jednak dla starożytnych odrzucenia jakiejkolwiek nadziei na własną wielkość. Moralność antyczna pielęgnowa-

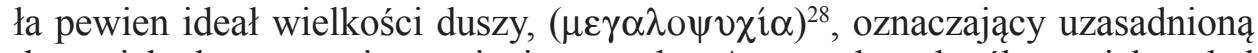
dumę i będący przeciwstawieniem pychy. Arystoteles określa go jako „ład

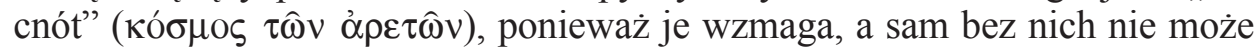

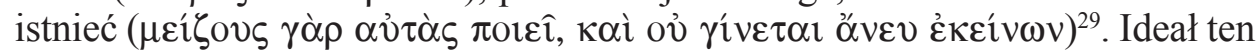
polegał na uznaniu siebie za zdolnego do wielkich rzeczy, ponieważ takim się rzeczywiście jest, czyli na posiadaniu słusznej opinii o sobie samym i poczuciu własnej wartości. Powinien on cechować przede wszystkim filozofów i przejawiać się w postawach, które autor Etyki nikomachejskiej szczegółowo opisał:

„Człowiek [...], który jest słusznie dumny ( $\mu \varepsilon \gamma \alpha \lambda o ́ \psi v \chi o \varsigma)$, jest nim przede wszystkim ze względu na swój sposób odnoszenia się do czci i niesławy

${ }^{26}$ Hesiodus, Labores et dies 5-8, ed. P. Mazon, Paris 1977, 86, thum J. Łanowski: Hezjod, Prace i dni, w: tenże, Narodziny bogów (Theogonia), Prace i dni, Tarcza, Warszawa 1999, 61. Por. Diogenes Laertios, Vitae philosophorum I 3, 69, ed. Huebnerus, t. 1, s. 46, tłum. I. Krońska - K. Leśniak - W. Olszewski - B. Kupis: Diogenes Laertios, Żywoty i poglady stynnych filozofów, Warszawa 1984, 45-46.

${ }^{27}$ Por. Gauthier, Magnanimité, s. 185-210. 406-407.

${ }^{28}$ Por. tamże, s. 250. Dosłownie można słowo to thumaczyć jako „wielkoduszność”, co wywołuje jednak skojarzenia z postawą wyrozumiałości czy życzliwości, zupełnie niezwiązaną z aspektem znaczeniowym, o który chodzi w interesującym nas kontekście.

${ }^{29}$ Por. Aristoteles, Ethica nicomachea IV 7, 1124 a, ed. Susemihl - Apelt, s. 80, thum. Gromska, s. 155. 
i cieszy się w sposób umiarkowany zaszczytami wielkimi i pochodzącymi od ludzi szlachetnych [...], lekceważyć natomiast będzie zaszczyty pochodzące od byle kogo i z powodów czynów bez znaczenia [...] jego sposób odnoszenia się do bogactwa, władzy i w ogóle do powodzenia i niepowodzenia, [...] będzie pełen umiarkowania i nie będzie człowiek taki ani zbytnio cieszył się powodzeniem, ani zbytnio martwił niepowodzeniem. [...] Człowiek słusznie dumny [...] skłonny jest do świadczenia dobrodziejstw, lecz kiedy ich doznaje, wstydzi się (pierwsze bowiem jest rzeczą tego, kto ma nad kimś przewagę, drugie - rzeczą tego, nad którym się ją ma). [...] Ludzie słusznie dumni zdają się też pamiętać o tych, którym wyświadczyli jakąś przysługę, zapominać zaś o tych, od których doznali przysług; bo ktoś, komu wyświadczono przysługę, jest w gorszym położeniu od tego, kto ją wyświadczył, człowiek zaś słusznie dumny pragnie mieć przewagę. [...] Jest dalej właściwością ludzi słusznie dumnych nie dążyć do tego, z czym łączą się zazwyczaj zaszczyty lub w czym przodują inni, lecz raczej zachowywać się pod tym względem biernie i ociągać się, chyba że idzie o wielkie zaszczyty lub wielkie dzieło, i przedsiębrać niewiele, ale za to rzeczy wielkich i godnych rozgłosu. [...] Dalszą cechą człowieka słusznie dumnego jest niemożność stosowania się w życiu do kogoś innego, chyba do przyjaciela; takie bowiem stosowanie się ma w sobie coś niewolniczego [...]. Człowiek słusznie dumny nie jest skłonny do podziwu, ponieważ nic nie wydaje mu się wielkim. I nie jest mściwy; bo człowieka słusznie dumnego cechuje nie skłonność do pamiętania, zwłaszcza o doznanych krzywdach, lecz raczej umiejętność puszczania w niepamięć" 30 .

Z powyższej charakterystyki wynika, że słuszna duma jest zastosowaniem swoiście rozumianej zasady umiaru do relacji człowieka z otaczającym światem. W wielu miejscach opis tej postawy zbiega się z późniejszym modelem stoickiego mędrca zachowującego wypracowaną przez lata umiarkowaną obojętność ( $\alpha \pi \alpha ́ \alpha \varepsilon \imath \alpha$ ) wobec wszelkich bodźców pochodzących z zewnątrz ${ }^{31}$.

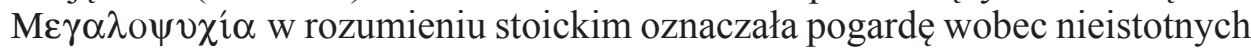
spraw zewnętrznych, która jest równocześnie afirmacją wielkości człowieka. Okazywanie jakiejkolwiek życiowej słabości, przejawiające się w prośbie o udzielanie pomocy, sprzeciwiałoby się takiej postawie.

Istotne dla Arystotelesa było połączenie w postawie człowieka uzasadnionej dumy z powodzenia rozumianego w kategoriach ziemskich $\mathrm{z}$ doskonałością etyczną. Ona jest gwarantem, że człowiek żywiący uzasadnioną dumę z powodu otaczającej go czci nie przekroczy zasady umiaru i nie popadnie w pychę i zuchwalstwo. Uzupełniająca wobec tak rozumianej słusznej dumy jest - według Arystotelesa - cnota umiarkowania, skromności ( $\sigma \omega \varphi \rho \circ \sigma u ́ v \eta)$,

\footnotetext{
${ }^{30}$ Tamże IV 7, 1124a - 8, 1125a, ed. Susemihl - O. Apelt, s. 80-84, thum. Gromska, s. 155-158.

${ }^{31}$ Por. M. Kozera, Ideały Ojców pustyni. Pathos $i$ apatheia, Lublin 2000, 201-261.
} 
która odnosi się, analogicznie, tylko do słabych, którzy uważają się za zdolnych do małych rzeczy, bo rzeczywiście takimi są ${ }^{32}$.

Opisany przez autora Etyki nikomachejskiej ideał etyczny łączył zachowania, które z punktu widzenia późniejszej chrześcijańskiej koncepcji pokory wydają się nieco sprzeczne. $Z$ jednej strony bowiem Arystoteles postulował umiar wobec wszelkich przesadnych ocen płynących z zewnątrz, oraz stawanie w prawdzie o sobie, co było akceptowalne dla chrześcijan i stanowiło w ich przekonaniu cechę charakterystyczną człowieka pokornego; z drugiej strony stawiał człowieka słusznie dumnego po stronie ludzi lepszych, mocniejszych, zadowolonych z tego, że siłą własnej woli doszli do postawy dzielności etycznej. Takie zachowanie musiało w chrześcijaństwie uchodzić za przejaw wyniosłości i pychy, a przede wszystkim naruszało postawę pokory wobec najważniejszego Bytu, czyli Boga Stwórcy i Dawcy wszelkiej doskonałości moralnej. U Ojców Kościoła postawa słusznej dumy, czyli dobrego mniemania o sobie, zostanie ściśle związana z pokorą: człowiek powinien nie tylko znać swoją godność, ale również pamiętać, że zawdzięcza ją Bogu. Natomiast według filozofów antycznych ludzka postawa okazująca jakąś niewystarczalność i brak, która w chrześcijaństwie będzie się przejawiać w pokornej modlitwie prośby do Boga, byłaby przejawem słabości, podczas gdy człowiek powinien rozpoznawać swoją prawdziwą wielkość. Arystoteles pisał:

„Charakterystyczną cechą człowieka słusznie dumnego jest [...], że o nic lub

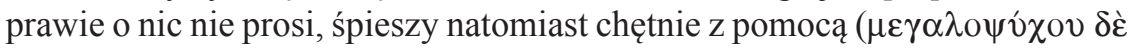

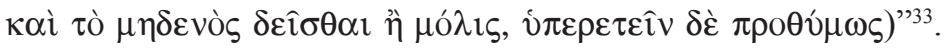

W późnym platonizmie, u Plotyna, spotykamy pojęcie $\tau o ́ \lambda \mu \alpha$, czyli zuchwałości, samowystarczalności w znaczeniu uniezależnienia się od boga:

„cóż właściwie sprawiło, że dusze zapomniały o swoim ojcu bogu i chociaż są «stamtąd» jako części i całkowicie doń należą, popadły w nieświadomość

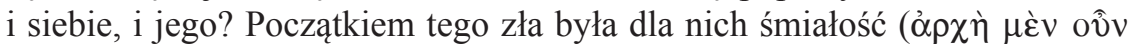

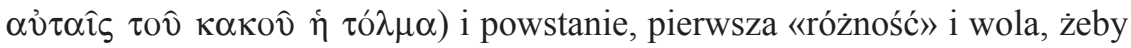

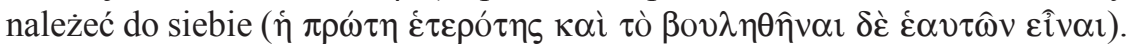
Uradowała je widocznie niezależna swoboda ( rzystając z wielkiej ruchliwości własnej, pomknęły w przeciwnym kierunku i odstąpiły bardzo daleko i oto popadły w niewiedzę, że i same «stamtąd» pochodzą, podobnie jak dzieci, oddzielone zaraz od początku od rodziców i wychowane w oddaleniu przez czas długi, nie wiedzą ani o sobie, ani o swoich rodzicach" ${ }^{34}$.

${ }^{32}$ Por. Aristoteles, Ethica nicomachea IV 7, 1124a - 8, 1124b, ed. Susemihl - Apelt, s. 80-83. Zob. Adnès, Humilité, DSp VII 1138.

${ }^{33}$ Aristoteles, Ethica nicomachea IV 8, 1124b, ed. Susemihl - Apelt, s. 82, thum. Gromska, s. 157. Por. Epictetus, Dissertationes I 6, 28-29, ed. H. Schenk1, Bibliotheca Scriptorum Graecorum et Latinorum Teubneriana, Lipsiae 1898, 23-24; tamże II 16, 11-15, ed. Schenk1, s. 153-154.

${ }^{34}$ Plotinus, Enneades V 1, 1-10, ed. É. Bréhier, t. 5, Paris 1931, 15, tłum. A. Krokiewicz: Plotyn, 
Do Plotyńskiego pojęcia $\tau o ́ \lambda \mu \alpha$ nawiąże Augustyn uznając pyszną i wyniosłą zuchwałość (audacia) za istotę grzechu ${ }^{35}$. Jak zauważył Pierre Adnès, dla Hippończyka drogą powrotu do Boga, a zarazem sposobem osiągnięcia najwyższego celu, jest pokora przeciwna owej pysznej zuchwałości, podczas gdy dla Plotyna drogą tą jest nie mające nic wspólnego z pokorą przypomnienie sobie o boskim pochodzeniu i godności duszy ${ }^{36}$.

Wracając do greckiego ideału słusznej dumy ( $\mu \varepsilon \gamma \alpha \lambda \circ \psi v \chi i \alpha)$ należy zwrócić uwagę na jeszcze jeden istotny rys charakteryzujący pojmowanie go przez Arystotelesa. Podkreślał on, że owa uzasadniona duma jako cnota jest ściśle związana z zasadą słusznego środka, ponieważ zajmuje miejsce pośrednie między małodusznością, graniczącą z nieśmiałością ( $\mu 1 \kappa \rho \circ \psi v \chi i \alpha)$, która polega na uznawaniu siebie za zdolnego tylko do małych rzeczy, podczas gdy jest się zdolnym do wielkich, a próżnością połączoną z zarozumialstwem ( $\chi \propto v \vee o ́ \tau \varepsilon \varsigma)$, która - przeciwnie - nakazuje uznawać się za zdolnego do rzeczy wielkich, podczas gdy jest się zdolnym tylko do małych ${ }^{37}$. Człowiek określany mianem $\chi \alpha \hat{v}$ vos to głupiec, który nie zdaje sobie sprawy ze swojej nicości i porywa się na wielkie sprawy: wynosi się nad innych, jest arogancki i pogardliwy. Stanowi karykaturę człowieka słusznie dumnego $(\mu \varepsilon \gamma \alpha \lambda \text { ó } \psi v \chi \circ \varsigma)^{38}$. Stoicy, piętnując wadę pychy, określali ją wymownym terminem - „dym”

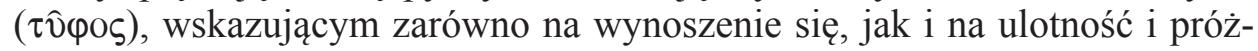
ność. Takiej postawie przeciwstawia się cnota - $\alpha \tau v \varphi \hat{\alpha} \alpha$, czyli brak próżnej zarozumiałości, przejawiający się w przyjmowaniu z obojętnością zarówno złych, jak i dobrych opinii o sobie ${ }^{39}$.

W antycznej myśli greckiej pojawiało się również pojęcie uniżenia, określane terminami $\tau \alpha \pi \varepsilon^{\prime} v \omega \sigma ı \varsigma$ lub $\tau \alpha \pi \varepsilon \imath$ ó $\left.\tau\right\rceil$, używanymi także w Piśmie Świętym, a następnie w greckiej literaturze patrystycznej na oznaczenie cnoty pokory obok terminu $\tau \alpha \pi \varepsilon \imath v o \varphi \rho o \sigma u ́ v \eta$. U starożytnych Greków terminy te miały jednak raczej sens pejoratywny i oznaczały małość, słabość, nędzę ${ }^{40}$. Identyfikowano je nawet z niską samooceną i przeciwstawiano słusznej dumie

Enneady, t. 2, Warszawa 2001, 506. Por. R. Arnou, Le Désir de Dieu dans la philosophie de Plotin, Paris, [1921?], 49-50. 222-227.

${ }^{35}$ Por. Augustinus, De civitate Dei XXII 24, 15-20, ed. B. Dombart - A. Kalb, CCL 48, Turnhout $1955,847$.

${ }^{36}$ Por. Adnès, Humilité, DSp VII 1139.

${ }^{37}$ Aristoteles, Ethica nicomachea IV 7, 1123b, ed. Susemihl - Apelt, s. 79-80.

${ }^{38}$ Tamże IV 9, 1125a, ed. Susemihl - Apelt, s. 83-84. To, co Arystoteles zawarł w jednym termi-

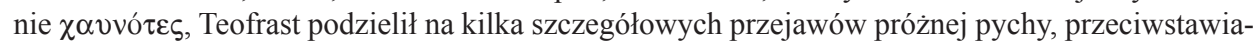
jących się uzasadnionej dumie. Są to: ambicja w drobnostkach ( $\mu \iota \kappa \rho о \varphi \imath \lambda o \tau \imath \mu i ́ \alpha)$, przechwalanie się ( $\dot{\lambda} \lambda \alpha \zeta o v \varepsilon i ́ \alpha)$, zuchwałość połączona z pogardą ( $(\pi \varepsilon \rho \eta \varphi \alpha v i ́ \alpha)$. Por. Theophrastus, Characteres 21. 23-24, ed. J.M. Edmonds, Loeb Classical Library, London - Cambridge Mass. 1961, 92-96. 98-104. Por. Adnès, Humilité, DSp VII 1139; Gauthier, Magnanimité, s. 407.

${ }^{39}$ Por. Diogenes Laertios, Vitae philosophorum VII 1, 117, ed. Huebnerus, t. 2, Lipsiae 1831, 164-165, tłum. Krońska - Leśniak - Olszewski - Kupis, s. 422-423.

${ }^{40}$ Por. Abramowiczówna IV 279. 
( $\mu \varepsilon \gamma \alpha \lambda \circ \psi v \chi i \alpha)$, charakterystycznej dla mędrca. Przykładowo w Moraliach

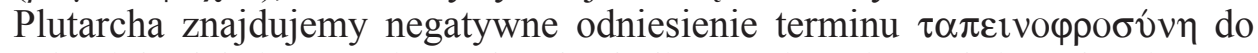
człowieka lękającego się trudnych okoliczności życiowych i pozbawionego odwagi:

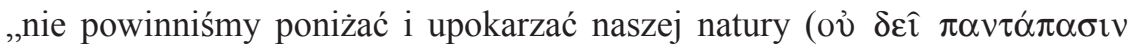

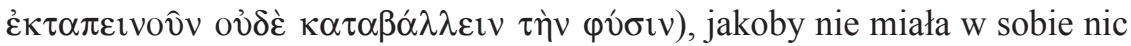
trwałego, nic silnego, nic wyższego nad ciosy losu; przeciwnie, zdajemy sobie sprawę, że mała tylko cząstka istoty ludzkiej jest krucha, podległa śmierci i losowi, a lepszej cząstki panami sami jesteśmy. [...] los może nas dotknąć niemocą, odebrać majątek, oczernić przed ludem lub przed władcą; ale uczynić nikczemnym lub tchórzliwym, niskim ( $\tau \alpha \pi \varepsilon ı$ vó $\rho \omega \nu)$, nieszlachetnym, zawistnym męża dzielnego, odważnego, mającego słusznie wzniosłe mniemanie o sobie ( $\mu \varepsilon \gamma \alpha \lambda o ́ \psi v \chi \circ \varsigma)$ nie może, tak jak nie może mu odjąć zasad, które, jeśli ma, są dlań czymś ważniejszym w życiu niż sternik na okręcie"41.

W Prawach Platona znajduje się jednak tekst, cytowany później przez Ojców, w którym słowo $\tau \alpha \pi \varepsilon$ เvós nabiera pozytywnego znaczenia. Oznacza ono umiarkowanie, które przeciwstawia się úßpıs i zbliża człowieka do Boga:

„[Bogu] towarzyszy [...] zawsze Sprawiedliwość, gardzicieli prawa bożego mścicielka. Trzyma się jej ten, kto chce wieść szczęsny żywot, i podąża w jej

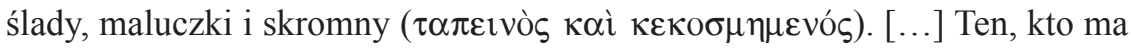

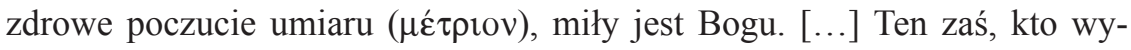
nosi się chełpliwie i dumny ze swego bogactwa, zaszczytów czy piękności cielesnej, młodzieńczą butą i głupotą pali się w duszy i pychą się wydyma

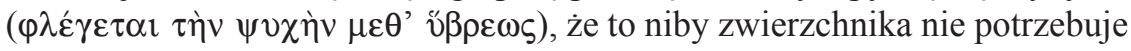
ani przewodnika, lecz sam zdolny jest przewodzić innymi, odrzucony zostaje

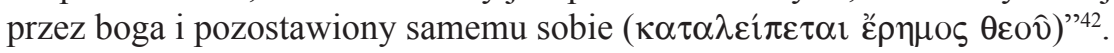

Powyższa wypowiedź Platona, chwaląca uniżenie ( $\tau \alpha \pi \varepsilon i v \omega \sigma \iota \varsigma)$, które przeciwstawia się pysze (őßpıৎ) i zbliża człowieka do Boga, była później cytowana i komentowana przez pisarzy wczesnochrześcijańskich, szczególnie w środowisku aleksandryjskim, jako dowód istnienia ziaren Bożej mądrości w antycznej filozofii greckiej ${ }^{43}$.

${ }^{41}$ Plutarchus, De tranquillitate animi 17, ed. G.N. Bernardakis, w: Plutarchus Cheronensis, Moralia, Bibliotheca Scriptorum Graecorum et Romanorum Teubneriana, t. 3, Lipsiae 1891, 235 236, tłum. Z. Abramowiczówna: Plutarch z Cheronei, O pogodzie ducha, w: tenże, Moralia. Wybór pism filozoficzno-popularnych, Wrocław 2005, 335 (tłum. poprawione). Por. Aristoteles, Rhetorica

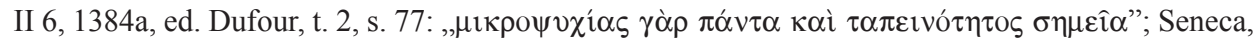
De constantia sapientis X 2-3, ed. R. Waltz, w: Sénèque, Dialogues, t. 4, Paris 1927, 48-49: „sine quadam humilitate [...] sapiens [...] magnitudinem animi suam novit”. Zob. Adnès, Humilité, DSp VII 1140.

${ }^{42}$ Plato, Leges IV 715e - 716b, ed. Bury, t. 1, s. 294-296, tłum. Maykowska, s. 147-148.

${ }^{43}$ Por. Clemens Alexandrinus, Stromata II 22, 132-133, ed. C. Mondésert - P.Th. Camelot, SCh 38, Paris 1954, 134, tłum. J. Niemirska-Pliszczyńska: Klemens Aleksandryjski, Kobierce zapisków 
Wśród przytoczonych poglądów etycznych starożytnych pisarzy greckich można odnaleźć zarówno pewne elementy zapowiadające chrześcijańską koncepcję pokory, jak i takie, które istotnie od niej się różnią ${ }^{44}$. Pychę uważano wprawdzie za główną wadę, ale przeciwstawiano jej nie pokorę, ale opartą na zasadzie umiaru postawę słusznej, uzasadnionej dumy, wynikającej z poczucia własnych możliwości. Cnota ta - którą można określić jako poczucie własnej wartości - była zarezerwowana dla osób zdolnych do etycznej dzielności, moralnie silnych. Postawę, którą chrześcijaństwo uznało za cnotę pokory, kojarzono w starożytności albo ze skromnością, czyli odpowiednikiem słusznej dumy odnoszącym się do ludzi słabych, niezdolnych do wielkich rzeczy; albo uważano za nieśmiałość, lęk czy tchórzostwo. Jeżeli więc autorzy wczesnochrześcijańscy przejmą pojęcia wypracowane przez myślicieli antycznych, nadadzą im nieco inne znaczenie, chociaż niekiedy będą sugerować, że antyczni myśliciele rozumowali w sposób zbliżony do chrześcijan. Największa różnica będzie dotyczyć religijnego wymiaru postawy pokory. Człowiek starożytny miał wprawdzie nie wywyższać się ponad bogów i okazywać im cześć i posłuszeństwo, ale równocześnie odczuwał wobec nich lęk, czuł się zależny od wszechwładnego fatum. Ponadto akcentował własną pracę przy osiągnięciu doskonałej postawy wielkodusznego mędrca. Chrześcijaństwo natomiast zwracało uwagę na osobę Stwórcy, od którego pochodzi wszelkie dobro, do jakiego człowiek jest zdolny. Również głosiło zasadę posłuszeństwa i uniżenia wobec Boga, ukazywało Go jednak jako kochającego Ojca, z którym człowiek jest związany nie tylko przez dobrowolny akt powołania do życia, ale także przez pełne miłości dzieło zbawienia, bez którego tkwiłby bezradnie w grzechu i śmierci.

\section{THE IDEA OF THE HUMBLE LOWLINESS \\ IN THE ANCIENT GREEK THOUGHT}

\section{(Summary)}

Even though the ancient Greeks did not recognize humility as a virtue, in the later Christian sense, their literature (Solon, Hesiod, Herodotus, Euripides) and philosophy (Plato, Aristotle, Theophrastus, stoics, Plutarch, Plotinus) contains some elements of the idea of the humble lowliness. Pride - considered as the greatest vice - was not contrasted with humility, but with the attitude of just pride arising from a based on the principle of moderation sense of finding oneself sufficient and confident in one's own capabilities. This virtue - which can be defined

filozoficznych dotyczacych prawdziwej wiedzy, t. 1, Warszawa 1994, 217; Origenes, Contra Celsum VI 15, ed. M. Borret, SCh 147, Paris 1969, 214-218, thum. S. Kalinkowski: Orygenes, Przeciw Celsusowi, Warszawa 1986, 297-298 (thum. poprawione).

${ }^{44}$ Por. Rehrl, Das problem der Demut, s. 199-203; Gauthier, Magnanimité, s. 489-491; Adnès, Humilité, DSp VII 1141. 
as a sense of self-worth - was reserved for those capable of ethical courage, the morally strong. The attitude that Christianity considered as the virtue of humility was associated in antiquity with modesty, which was the equivalent of a just pride, referring to the weak people, unfit to accomplish great deeds, or with shyness, fear or cowardice.

Słowa kluczowe: cnota, idea umiaru, postawa słusznej dumy, pokora, pycha, literatura starożytnej Grecji, Solon, Herodot, Platon, Arystoteles, Teofrast, Plutarch.

Key words: virtue, idea of moderation, attitude of just pride, humility, pride, ancient Greek literature, Solon, Herodot, Plato, Aristotle, Theophrastus, Plutarch. 
